\title{
Membrane Phosphoproteins of Rat Hippocampus: Sensitivity to Tetanic Stimulation and Enkephalin
}

\author{
P. R. BÄR, A. M. TIELEN, F. H. LOPES DA SILVA, H. ZWIERS and W. H. GISPEN \\ (P.R.B., H.Z. and W.H.G.) Institute of Molecular Biology and Rudolf Magnus Institute for Pharmacology, State University of \\ Utrecht, Padualaan 8, 3508 TB Utrecht and (A.M.) Institute for Medical Physics, MFI-TNO, Da Costakade 45, 2861 PN \\ Utrecht and (F.H.L. da S) University of Amsterdam, Department of Animal Physiology, Kruislaan 318, 1098 SM \\ Amsterdam (The Netherlands)
}

(Accepted January 7th, 1982)

Key words: tetanic stimulation - hippocampal slice - cAMP-independent phosphorylation — post-tetanic stimulation perforant path — phosphoproteins - methionine-enkephalin

\begin{abstract}
Hippocampal slices are electrically stimulated in the perforant path with a pulse-train, which can lead to long-term potentiation (LTP). Of the thus stimulated slices, subcellular fractions are prepared and used in an endogenous protein phosphorylation assay. A phosphoprotein band which was reported earlier to be sensitive to electric stimulation as well as to methionine-enkephalin is now further analyzed: it consists of two phosphoproteins only slightly differing in molecular weight: $50,000 \mathrm{M}_{\mathrm{r}}(50 \mathrm{~K})$ and $52,000 \mathrm{M}_{\mathrm{r}}$ $(52 \mathrm{~K})$, but having distinct biochemical properties and subcellular localization. Their IEP is dissimilar (3.5-4.3 and 5.3, respectively), they display different sensitivity towards calcium when tested in the phosphorylation assay, but are both cAMPindependently phosphorylated. Only one of them responds to tetanic stimulation with an increased phosphorylation post hoc. This protein, the $52 \mathrm{~K}$ component, is localized in synaptic membranes. Moreover, this protein also responds to incubation of slices with methionine-enkephalin. The phosphorylation of the $50 \mathrm{~K}$ component is not influenced by electric stimulation, nor by incubations with neuropeptides; its phosphorylation takes place in material sedimenting with the mitochondrial cell fractions and is strongly calcium- and calmodulin-dependent.
\end{abstract}

\section{INTRODUCTION}

In correlative studies on electrical and neurochemical parameters the transversal slice of the hippocampus is suitable to use as it combines good responses to electric stimuli with a relatively good accessibility for the study of biochemical parameters. Under the appropriate conditions these slices can be maintained in vitro up to $32 \mathrm{~h}^{44,48,51}$. Owing to the lamellar organization of the hippocampus ${ }^{2,3,24}$, the slices still have a virtually intact trisynaptic pathway (perforant path: granular cells - mossy fibers: CA3 pyramidal cells - Schaffer collaterals: CA1 pyramidal cells; for review see ref. 30). Several groups have described the generation of long-term potentiation (LTP) by tetanic stimulation in one of the three monosynaptic pathways of the hippocampal slice $1,15,43$. Presumably the LTP is accompanied by swelling of dendritic spines, which may underly the increased synaptic efficacy ${ }^{18}$. In addition, Lee et al. ${ }^{29}$ reported that the number of shaft synapses increased after stimulation of slices. Recently, the effect of tetanic stimulation and the subsequent development of LTP on protein phophorylation, measured in a post hoc endogenous phosphorylation assay, was studied. Browning et al. ${ }^{10}$ observed that after high frequent stimulation in the Schaffer collaterals one protein band in particular $\left(M_{r}\right.$ 40,000) incorporated less phosphate when a fraction prepared from the treated slices was assayed afterwards in a phosphorylation assay. Later they reported that this band was phosphorylated in vitro by phosphorylase kinase ${ }^{9}$ and on basis of studies on MW and proteolytic fingerprinting they recently reported $^{8}$ that the $40 \mathrm{~K}$ protein probably is the $\alpha$ subunit of pyruvate dehydrogenase. It appeared that the phosphorylation of this enzyme in the brain is also responsive to behavioral experience ${ }^{42}$. Using an experimental set up comparable but not identical to that used by Browning et al. ${ }^{10}$, we reported that 
another protein band $\left(\mathrm{M}_{\mathrm{r}} 50,000\right)$ was also responsive to tetanic stimulation. The so-called $50 \mathrm{~K}$ band shows an enhanced phosphorylation after stimulation $^{6}$ and is sensitive to methionine-enkephalin ${ }^{5}$. As discussed elsewhere ${ }^{6,31}$, there is reason to believe that the interval between tetanic stimulation and homogenization of the slices is one of the major factors determining the difference in effects mentioned in the studies of Browning ${ }^{10}$ and ourselves ${ }^{6}$. Browning finds that the maximum effect on the $40,000 \mathrm{M}_{\mathrm{r}}$ band occurs $2-5 \mathrm{~min}$ after the tetanus; after 10-15 min the effect has disappeared (personal communication). In our studies we wait $15 \mathrm{~min}$ before homogenizing the slices ${ }^{6}$.

In this report we present data indicating that the $50 \mathrm{~K}$ protein band in fact consists of two proteins with different biochemical properties and subcellular localization. Only one of the proteins is sensitive to electrical treatment and present in fractions enriched in synaptosomal plasma membranes.

\section{MATERIALS AND METHODS}

\section{Dissection and slice preparation}

Male Wistar rats of an inbred strain (TNO, Zeist, The Netherlands) weighing 120-150 g, were used. After decapitation, the brains were dissected and the hippocampi obtained within 3 min after death. They were kept in a Krebs-Ringer buffer $(\mathrm{NaCl} 124 \mathrm{mM}$; $\mathrm{KCl} 5 \mathrm{mM}, \mathrm{KH}_{2} \mathrm{PO}_{4} 1.24 \mathrm{mM} ; \mathrm{MgSO}_{4} 1.3 \mathrm{mM}$, $\mathrm{CaCl}_{2} 2.0 \mathrm{mM}, \mathrm{NaHCO}_{3} 26 \mathrm{mM}$, glucsoe $10 \mathrm{mM}$, $\mathrm{pH}$ 7.4). Before use, the buffer had been equilibrated with a mixture of $\mathrm{CO}_{2}$ and $\mathrm{O}_{2}(5 \% / 95 \%)$. Subsequently, hippocampal slices were cut (300-400 $\mu \mathrm{m}$ thickness) by hand, with a special multiple slice cutter. The slices were then put in a perspex chamber and kept under a continuous flow of humidified $\mathrm{CO}_{2} / \mathrm{O}_{2}$ (20-40 liter $\left./ \mathrm{h}\right)$, immersed in Krebs-Ringer buffer at $36^{\circ} \mathrm{C}$ as described before 6 .

\section{Tetanic stimulation}

After a preincubation of $60 \mathrm{~min}$ in the perspex chamber, a stimulating electrode was placed in the perforant path and a glass recording electrode in the stratum moleculare/stratum granulosum of the fascia dentata. In each slice a stimulus/response relationship was determined as described earlier ${ }^{6}$. The minimal current still giving rise to a population spike in the recorded area was chosen as stimulating current. Subsequently, a series of pulses was given using the same stimulation electrode during $15 \mathrm{~s}$ (15 pulses/s).

\section{Tissue fractionation}

Slices were taken out of the incubation chamber 15 min after stimulation and immediately homogenized in $100 \mu \mathrm{l}$ of an ice-cold sucrose solution $(0.32 \mathrm{M})$. Slices that were not stimulated but further equally treated and obtained from the same animal were used as controls. All procedures were performed at $0-4{ }^{\circ} \mathrm{C}$, unless stated otherwise.

Homogenization was performed in a small Potter-Elvehjem device (volume $100 \mu \mathrm{l}$ ) with a motor-driven pestle made of Teflon (700 rpm). Seven strokes were sufficient to give a homogeneous suspension. Homogenates of 5 slices were pooled and spun down at $1000 \mathrm{~g}$ for $10 \mathrm{~min}$. Thus a pellet was obtained containing mainly unbroken cells, nuclei and debris. The supernatant was carefully sucked off and spun again at $10,000 \times g$ for $20 \mathrm{~min}$. This pellet (P2) contains synaptosomes, mitochondria and membrane fragments. In some experiments this pellet was used in the endogenous protein phosphorylation assay. For further analysis the P2 pellet was lysed with 9 vols. of distilled water for 15 min. The lysate $(60 \mu \mathrm{l})$ then was layered on top of a small discontinuous gradient $(0.4 \mathrm{M}$ sucrose $1.3 \mathrm{ml}$; $1.0 \mathrm{M}$ sucrose, $2.2 \mathrm{ml}$ ) and spun down at $100,000 \mathrm{~g}$ for 80 min, according to the method of De Robertis et al. ${ }^{12,13}$. Material floating on top of the $1.0 \mathrm{M}$ layer was collected, diluted with an acetate buffer (sodium acetate $50 \mathrm{mM}$, magnesium acetate $10 \mathrm{mM}$, $\mathrm{pH} 6.5)$ and collected by centrifugation $(100,000 \mathrm{~g}$ for $20 \mathrm{~min})$. The thus washed membranes were resuspended in the sodium/magnesium acetate buffer resulting in a protein concentration of approximately $1 \mu \mathrm{g} / \mu \mathrm{l}$. This fraction is called t-SPM (see also Fig. 1).

When intact hippocampi were used to prepare a SPM fraction, the procedure described by Terenius ${ }^{46}$ and Zwiers et al. ${ }^{52}$ was followed: after lysis of the P2 pellet, the suspension was spun down at $10,000 \mathrm{~g}(10 \mathrm{~min})$. The supernatant, called P2-lyssup, containing light plasma membrane fragments, was layered on top of a gradient $(0.4 \mathrm{M}$ sucrose, 8 $\mathrm{ml}$; $1.0 \mathrm{M}$ sucrose, $8 \mathrm{ml} ; 1.2 \mathrm{M}$ sucrose, $8 \mathrm{ml}$ ). After 
centrifugation (100,000 $\mathrm{g}$ maximally, $80 \mathrm{~min}$ ), mate ial floating on the $1.0 \mathrm{M}$ layer was collected, washed and suspended as described above. This fraction, diluted with buffer to $1 \mu \mathrm{g} / \mu \mathrm{l}$ protein, was called LSPM (see also Fig. 1).

\section{Peptide incubation}

After cutting the slices, they were allowed to preincubate during $60 \mathrm{~min}$ in test tubes with $1 \mathrm{ml}$ of Krebs-Ringer buffer, as described before ${ }^{5}$. A continuous gas flow provided oxygen and gentle movement of the slices. The temperature was kept constant at $29{ }^{\circ} \mathrm{C}$. Ten min before adding methionineenkephalin (final concentration $10^{-5} \mathrm{M}$, dissolved in $100 \mu \mathrm{l}$ buffer) the buffer was replaced by fresh buffer to which bacitracin $(30 \mu \mathrm{g} / \mu \mathrm{l})$ was added. Incubation with peptide took $60 \mathrm{~min}$ at $36{ }^{\circ} \mathrm{C}$ and continuous $\mathrm{O}_{2} / \mathrm{CO}_{2}$ flow. These incubations were stopped by washing the slices twice with an ice-cold sucrose solution $(0.32 \mathrm{M})$ and immediate homogenization subsequently, as described above.

\section{Phosphorylation assay}

Subcellular fractions prepared from hippocampal slices or from total hippocampi were phosphorylated as described before 5 . In short: aliquots of SPM or P2 material (ca. $20 \mu \mathrm{g}$ protein) were incubated with labeled ATP. Unlabeled ATP was present yielding a total concentration of $7.5 \mu \mathrm{m}$ ATP (incubation volume $25 \mu \mathrm{l}$ ). When substances such as cAMP were tested they were added $15 \mathrm{~s}$ before starting the phosphorylation with ATP. After $15 \mathrm{~s}$ the incubations were stopped by adding a proteindenaturing mixture containing SDS and $\beta$-mercaptoethanol. The total resulting solution was applied to slab gels (polyacrylamide, $11 \%, 10 \mathrm{~cm}$ long, 1.0 $\mathrm{mm}$ thick) in slots with a volume of $50 \mu \mathrm{l}$. Proteins were separated during a run of 2-3 h (current 35 $\mathrm{mA}$, voltage $80-120 \mathrm{~V}$ ). After fixing and staining the thus separated proteins in a mixture of methanol: water :acetic acid (40:60:10, by volume) with $0.1 \%$ Fast Green, the gels were destained overnight, dried and used for autoradiography.

\section{Two-dimensional analysis of proteins}

Proteins from L-SPM and the P2 fraction were separated in the first dimension by isoelectric fo- cussing (IEF) in polyacrylamide slab gels. The procedure for casting and running the IEF gel was similar to that described by Zwiers et al. ${ }^{53}$, except that the gel contained $8.5 \mathrm{M}$ urea and $0.5 \%$ Triton $\mathrm{X}-100$. Before applying to the gel, the protein samples (100 $\mu \mathrm{g}$ protein, volume $20 \mu \mathrm{l}$ ) were phosphorylated (see above) and the reaction was stopped by freezing the samples in liquid nitrogen.

Membrane-bound proteins were dissolved by adding urea and Triton X-100 resulting in a final concentration of respectively $8.5 \mathrm{M}$ and $0.5 \%(\mathrm{v} / \mathrm{v})$. The mixtures were shaken vigorously for $1 \mathrm{~min}$ on a Vortex mixer and subsequently ampholines $(\mathrm{pH}$ range 3.5-10.0) and sucrose were added (final concentration $2.5 \%(\mathrm{w} / \mathrm{v})$ and $5 \%(\mathrm{w} / \mathrm{v})$ resp.). The IEF gel was run overnight at $200 \mathrm{~V}$. Individual tracks were excised and incubated for $2 \mathrm{~min}$ in $8 \mathrm{ml}$ of the following wash solution: $62.5 \mathrm{mM}$ Tris- $\mathrm{HCl}, \mathrm{pH}$ $6.8 ; 2 \%$ SDS $; 10 \%$ glycerol $; 0.01 \%$ bromophenolblue and $5 \% 2$-mercaptoethanol. The washed tracks were run in the second dimension on SDS-polyacrylamide slab gels as described before ${ }^{53}$. Gels were stained for protein, dried, and subjected to autoradiography.

\section{Preparation of calmodulin}

Calmodulin was prepared from calf brain by the method of Wallace and Cheung 50 .

Protein concentration was determined by the method of Lowry et al. ${ }^{32}$.

\section{Quantitation and statistics}

Incorporation of label into proteins was quantified in two ways. A scan was made of the autoradiograms, using a set up with higher resolving power as compared with earlier reports (Zeiss PMQII coupled to a Zeiss scanning densitometer, slit width $0.01 \mathrm{~mm}$, wave length $550 \mathrm{~nm}$ ). Peak heights above background were measured according to Ueda et al. ${ }^{49}$. In some instances phosphoproteins were cut out of gels, guided by the autoradiograph, and counted for radioactivity (in a Xylofluor/Triton $\mathrm{X}-100$ mixture, $23: 7$, by volume).

Statistical evaluation consisted of Student's $t$-test, two-tailed for non-paired data, if necessary preceded by one-way analysis of variance. 


\section{RESULTS}

\section{Localization studies}

In earlier reports we reported changes in endogenous phosphorylation of a $50,000 \mathrm{M}_{\mathrm{r}}$ protein band as a function of preceding tetanic stimulation $^{6,47}$. By direct comparison of the phosphoprotein of a P2 and a SPM fraction on the same gel, and by analysis of the autoradiograms using a slit width of $10 \mu \mathrm{m}$ instead of $100 \mu \mathrm{m}^{5,6}$, it became apparent that the $50 \mathrm{~K}$ band could be separated into two components with $\mathrm{M}_{\mathrm{r}}$ 50,000 and 52,000. They run very close together and the $52 \mathrm{~K}$ band does not always appear as a distinct band, due to the high incorporation of label into the nearby $50 \mathrm{~K}$ band (see Fig. 2, lane C) and often the $50 \mathrm{~K}$ band which in a P2 fraction is phosphorylated predominantly with respect to the $52 \mathrm{~K}$ band, overlaps the $52 \mathrm{~K}$ on the autoradiogram. In order to study the localization of these two proteins we prepared the following fractions of a rat hippocampal homogenate (see Fig. 1): a crude synaptosomal fraction (P2), a fraction enriched in light membranes and the contents of synaptosomes (P2-lys-sup), two synaptosomal membrane enriched fractions, (L-SPM and t-SPM) and a fraction enriched in mitochondria (P-mito). These fractions were assayed for endogenous phosphorylation and attention was focussed on bands in the 40-55,000 $\mathrm{M}_{\mathrm{r}}$ region.

\section{Fractionation scheme}

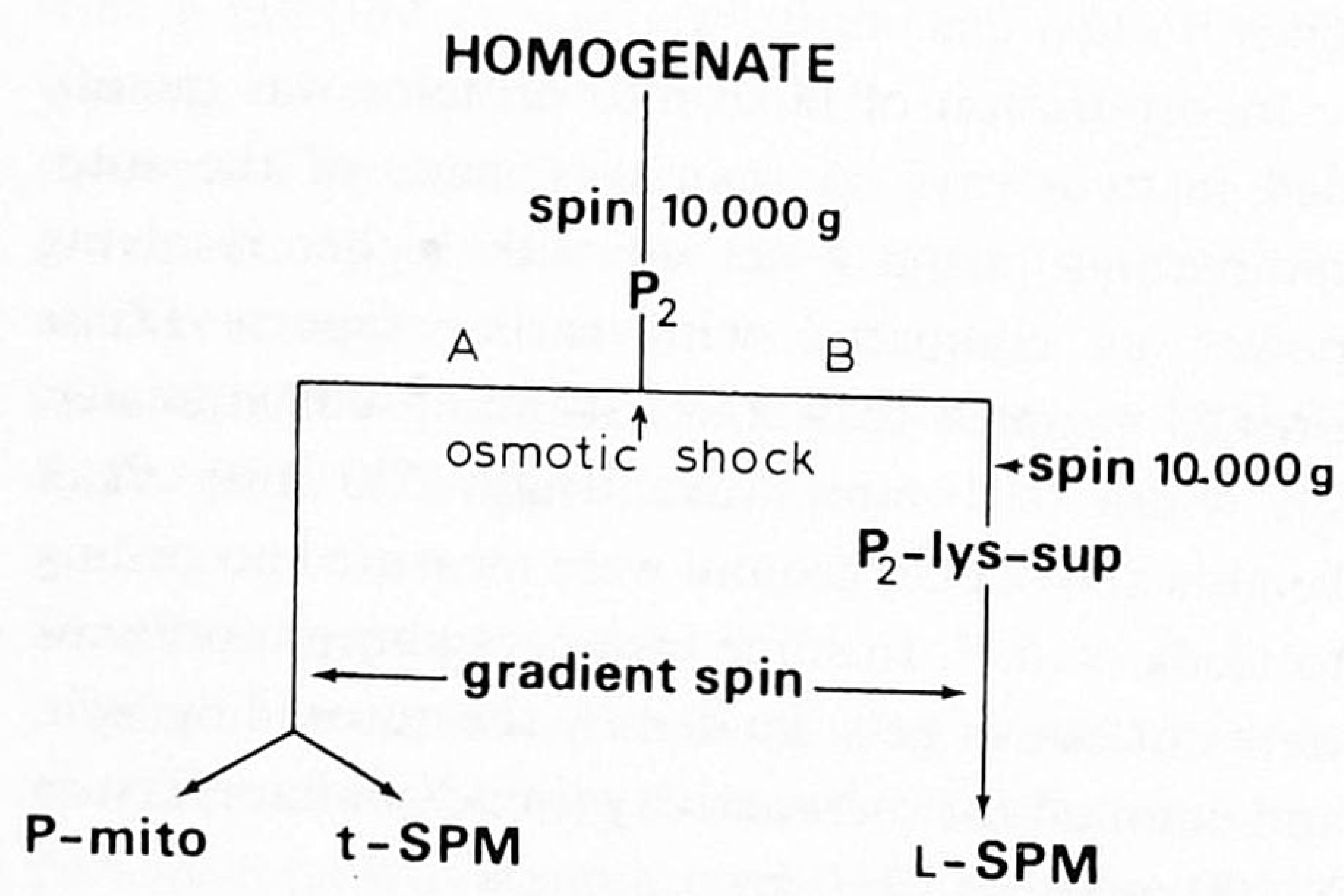

Fig. 1. Fractionation scheme; starting from slices or whole hippocampal tissue several fractions were prepared. Route (A) was used when up to 4 slices were homogenized, route (B) when more slices were pooled, or when whole hippocampi were used.

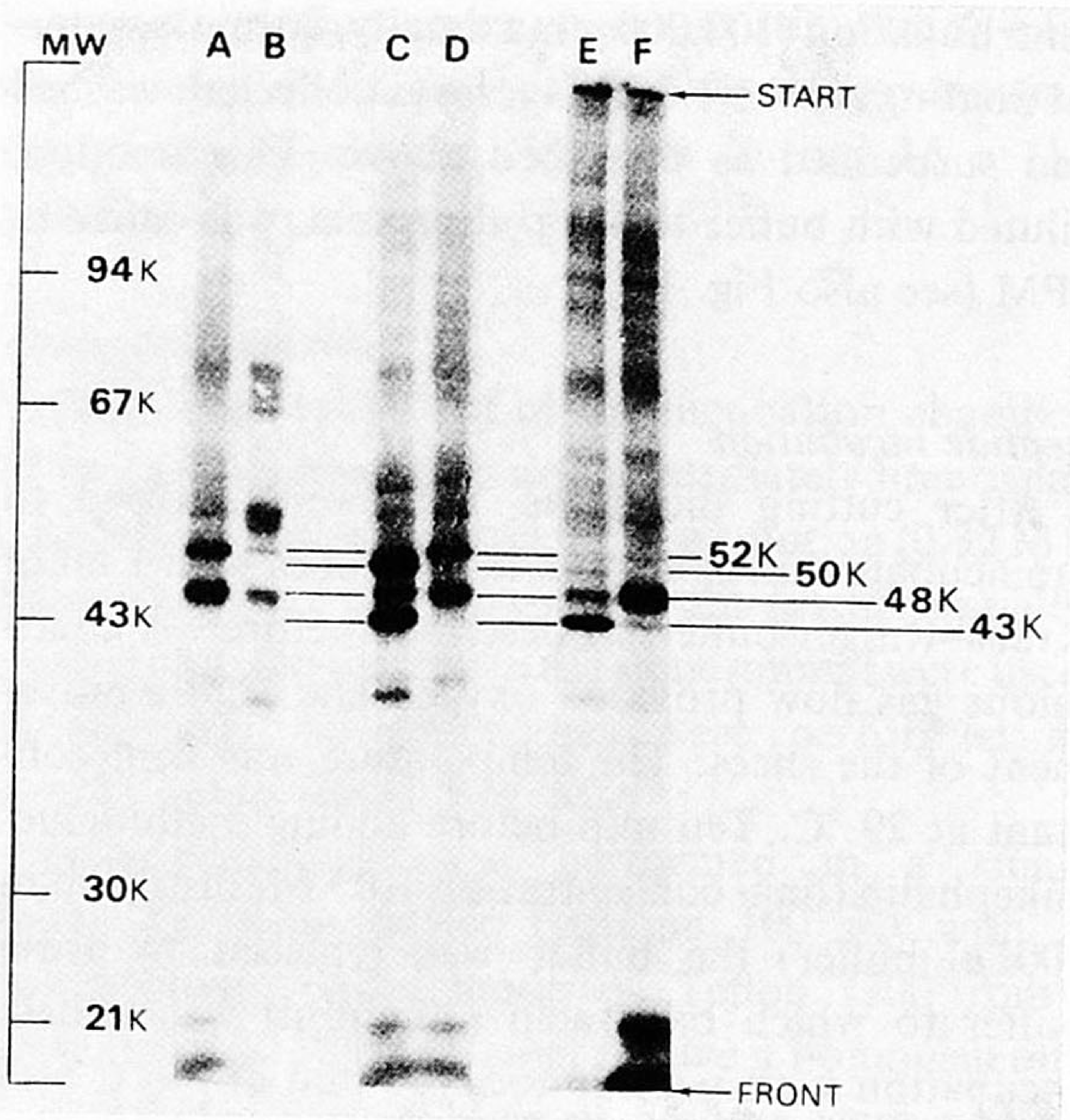

Fig. 2. Autoradiographs of phosphorylated subcellular fractions obtained from rat hippocampal tissue. Lane A, L-SPM; lane B, P2-lys-sup; Lane C; P2; lane D, L-SPM; lane E, Pmito; lane F, t-SPM. Positions of the MW marker proteins are indicated on the left.

In the P2 fraction (Fig. 2, lane C) all 4 major bands in this region are present: $43 \mathrm{~K}, 48 \mathrm{~K}, 50 \mathrm{~K}$ and $52 \mathrm{~K}$. In this fraction, which still contains mitochondria, $43 \mathrm{~K}$ and $50 \mathrm{~K}$ are predominantly phosphorylated. After an osmotic shock of this fraction unbroken vesicles and mitochondria are removed by sedimentation. The phosphorylation profile of the resulting P2-lys-sup (Fig. 2, lane B) shows that $43 \mathrm{~K}$ and $50 \mathrm{~K}$ are no longer present. When this fraction is further separated on a discontinuous sucrose gradient, the material floating on top of the $1.0 \mathrm{M}$ layer, L-SPM, shows a clear enrichment of $48 \mathrm{~K}$ and $52 \mathrm{~K}$ (Fig. 2, lanes A and D). We also prepared such a gradient fraction (t-SPM) from shocked P2, still containing intact and mitochondrial material. The tSPM fraction, though less pure than L-SPM, was used when only few slices of rat hippocampus were fractionated after electrical treatment. Such a fractionation procedure yields t-SPM, as well as a pellet enriched in mitochondria (P-mito). It should be kept in mind that although this procedure increases yield it also results in less pure material. As can be seen from Fig. 2, lane E, the P-mito fraction like the P2 contains all four major bands, $43 \mathrm{~K}$ being predominantly phosphorylated, whereas in the membrane 

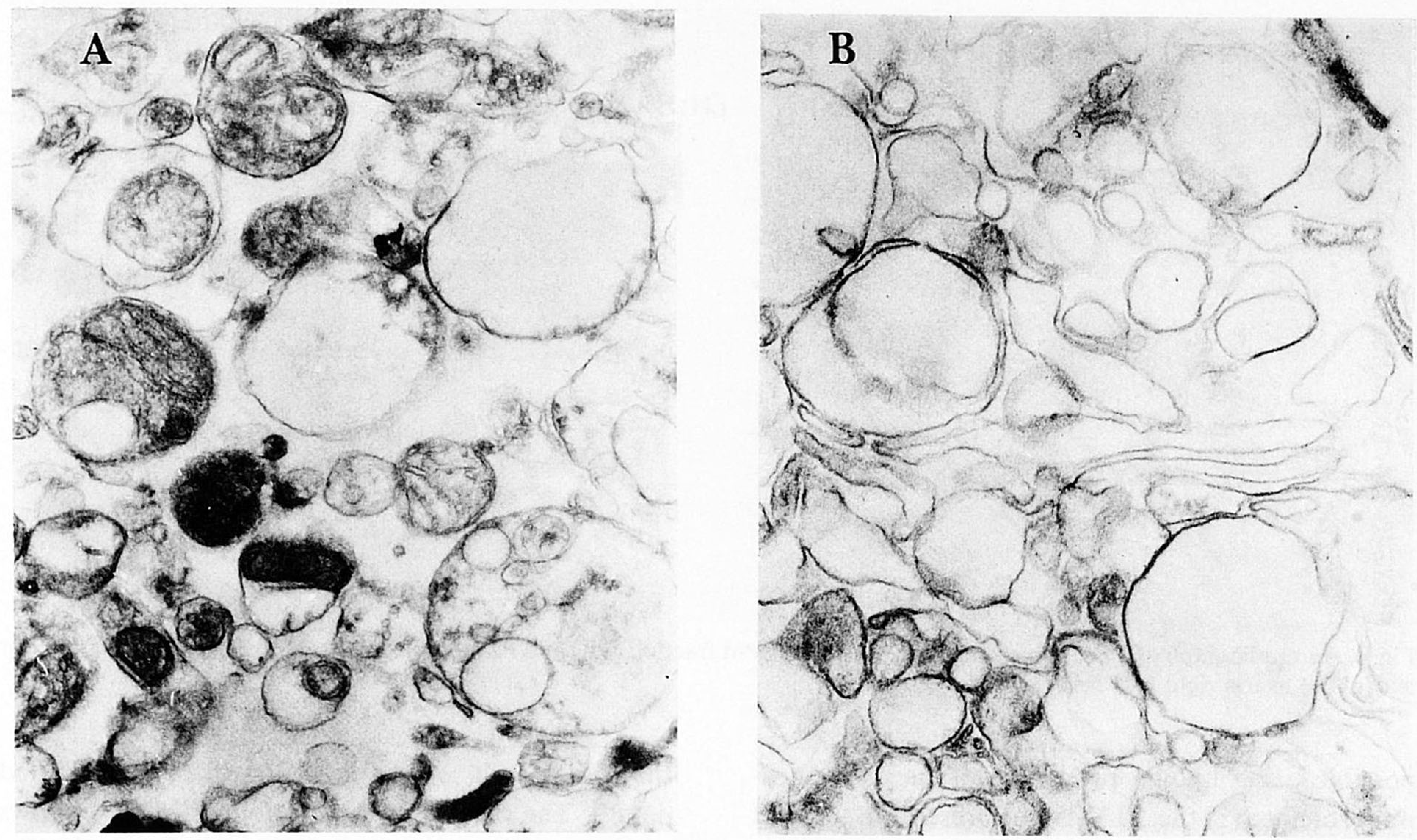

Fig. 3. Electron-microscopic pictures of two subcellular fractions prepared from rat hippocampus. A: P2 fraction. B: L-SPM fraction. $\times 44000$

fraction (t-SPM, Fig. 2, lane F) again $48 \mathrm{~K}$ and $52 \mathrm{~K}$ are enriched. Some $43 \mathrm{~K}$ phosphorylation is observable.

Fig. 3 shows electron microscopic pictures of the two extreme fractions used: the unpure P2 fraction (Fig. 3A) and the most enriched SPM fraction, the L-SPM (Fig. 3B). The P2 fraction shows intact synaptosomes with mitochondria, whereas in the LSPM picture the empty synaptosomal structures are obvious. Furthermore, this and other pictures show virtually no myelin or mitochondrial contamination of the L-SPM preparation.

\section{TABLE I}

Effect of tetanic stimulation on endogenous phosphorylation assayed in a P2 fraction (A), a $t$-SPM fraction (B) and a $P$-mito fraction ( $C$ )

\begin{tabular}{|c|c|c|c|c|c|c|}
\hline \multirow[t]{2}{*}{ Mol. wt. } & \multicolumn{2}{|c|}{ (A) $P 2$} & \multirow{2}{*}{$\frac{(B)}{\Delta \%}$} & \multirow{2}{*}{$\frac{t-S P M}{P}$} & \multicolumn{2}{|c|}{ (C) P-mito } \\
\hline & $\triangle \%$ & $P^{*}$ & & & $\triangle \%$ & $P$ \\
\hline $50 \mathrm{~K}$ & $* *$ & & not $p$ & esent & +4 & n.s. \\
\hline $52 \mathrm{~K}$ & +24 & $<0.01$ & +30 & $<0.02$ & +24 & $<0.05$ \\
\hline
\end{tabular}

* Student's $t$-test was used, two-tailed.

** Data taken from ref. $6 ; 50 \mathrm{~K}$ and $52 \mathrm{~K}$ were in that study not quantitatively separated.

\section{Tetanic stimulation}

As reported before, high frequent stimulation (15 pulses/s) during $15 \mathrm{~s}$ applied to the perforant path fibers of the hippocampal slice, resulted primarily in an increased phosphorylation of a $50 \mathrm{~K}$ band in a post hoc assay (ref. 6, data given in Table I). We now demonstrate that $50 \mathrm{~K}$ and $52 \mathrm{~K}$, components of the $50 \mathrm{~K}$ band, behave differently after a tetanic stimulation. The $50 \mathrm{~K}$ protein did not show any change in phosphorylation in a $\mathrm{P}$-mito fraction (see Table I). However, the $52 \mathrm{~K}$ protein, both in a $\mathrm{P}$ mito fraction and in the t-SPM showed a significant increase in ${ }^{32} \mathrm{P}$-incorporation after stimulation of $24 \%$ and $30 \%$, respectively (see Table I). We therefore conclude that the increase of $24 \%$ after tetanus observed earlier ${ }^{6}$ in a $\mathrm{P} 2$ fraction is attributable to the $52 \mathrm{~K}$ component of the $50 \mathrm{~K}$ band.

\section{Two-dimensional gel electrophoresis and determina- tion of IEP}

The proteins present in the P2 and L-SPM were separated two-dimensionally as described in the Materials and Methods section. Identification of the $50 \mathrm{~K}$ and $52 \mathrm{~K}$ proteins after autoradiography was 
FIRST DIMENSION: IEF $\longrightarrow$

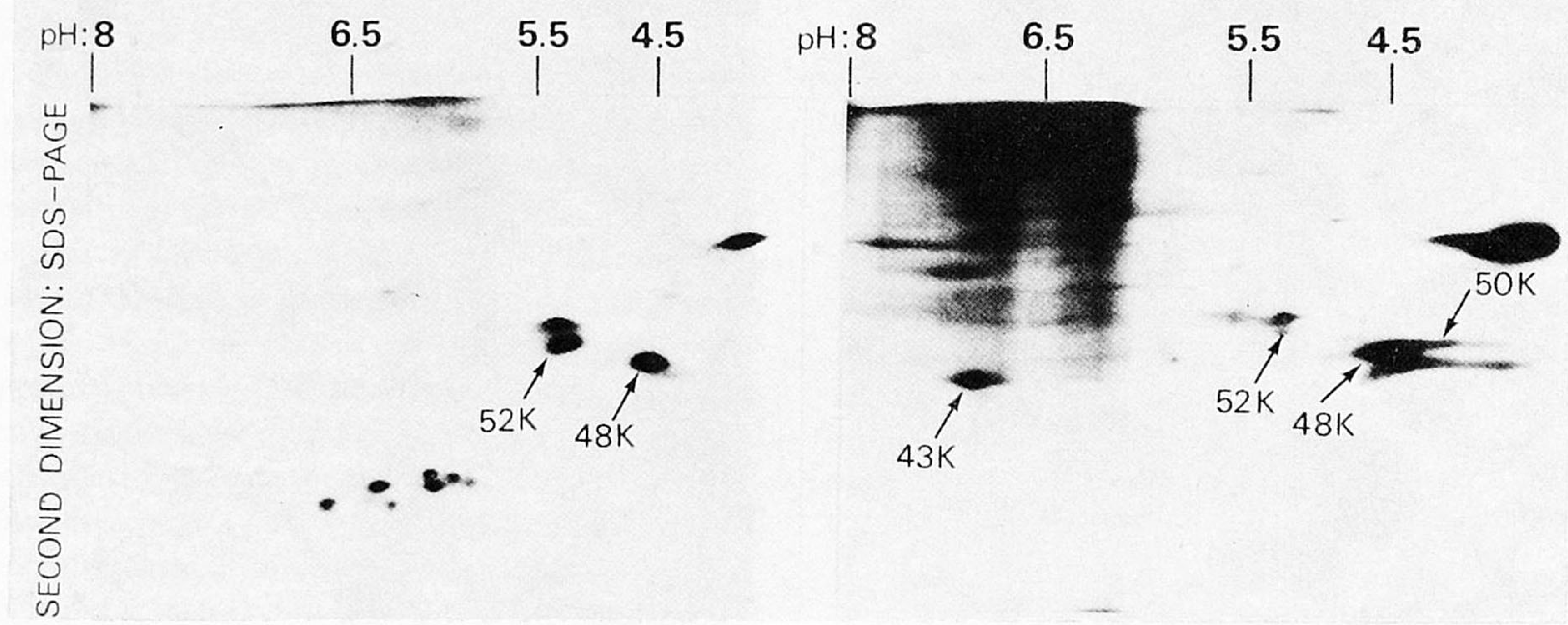

Fig. 4. Autoradiograph of a two-dimensionally separated L-SPM fraction (left) and P2 fraction (right). The pH-gradient is from top left $(\mathrm{pH} 8)$ to top right $(\mathrm{pH} 3.5)$.

possible using known properties of the two phosphoproteins: (1) the $50 \mathrm{~K}$ is not present in an SPM fraction; (2) the two different proteins show a different $\mathrm{Ca}^{2+}$-dependency (see next section); (3) MW-markers, as well as phosphorylated SPM fraction were always applied to the same SDS gel on which the second dimension separation was run. As Fig. 4 (left) shows, the $50 \mathrm{~K}$ protein appears to be heterogeneous after isoelectric focussing. The IEP of the components ranges from 3.5 to 4.3 . The $52 \mathrm{~K}$ protein is present as a minor phosphoprotein, with an IEP of 5.3. In Fig. 4 (left) the autoradiogram of phosphorylated and two-dimensionally separated LSPM proteins is shown. The $50 \mathrm{~K}$ protein is not present in this fraction, whereas the $52 \mathrm{~K}$ protein is one of the major phosphoproteins.

\section{Calcium, calmodulin and $c A M P$}

In a series of experiments the sensitivity of the phosphoproteins in the $\mathrm{P} 2$ fraction to various modulators was tested. The sensitivity to calcium was measured in the presence of $10 \mathrm{mM}$ magnesium and $1 \mathrm{mM}$ EGTA; the calcium concentration was varied from 0 to $50 \mathrm{mM}$.

The amount of labeled phosphate, incorporated into 4 proteins as a function of the calcium concentration is depicted in Fig. 5. The $48 \mathrm{~K}$ (Fig. 5B) and the $50 \mathrm{~K}$ (Fig. $5 \mathrm{C}$ ) protein show a clear optimum, both at 2-3 $\mathrm{mM}$ calcium. The calcium sensitivity of the $48 \mathrm{~K}$ protein is in agreement with earlier reported data $^{53}$. The $52 \mathrm{~K}$ phosphoprotein (Fig. 5D) shows no Ca-dependency over the range studied here. The $43 \mathrm{~K}$ protein displays a biphasic sensitivity to calcium: a stimulation at low, and an inhibition at high concentrations of calcium (Fig. 5A). In all curves the incorporation is indicated when no EGTA, or divalent cation is added exogenously.

The influence of calmodulin of the endogenous phosphorylation of the $50 \mathrm{~K}$ and $52 \mathrm{~K}$ protein is measured in a P2 fraction in the presence of EGTA $(1 \mathrm{mM})$ and varying calcium concentrations. Fig. 6 shows that the phosphorylation of the $43 \mathrm{~K}$ protein is stimulated with ca. $30 \%$ at all calcium concentrations. The $48 \mathrm{~K}$ proteins shows a shift in its optimal calcium concentration to a somewhat lower value, a phenomenon displayed by the $50 \mathrm{~K}$ protein in a more pronounced fashion: app. $45 \%$ more phosphate is incorporated (as established by cutting the proteins from the gel and liquid scintillation counting of the cut gel parts), and the optimal calcium concentration in the presence of calmodulin is shifted to a lower value $\left(8 \times 10^{-3}\right.$ versus $10^{-3}$ with calmodulin).

When studied in a P2 fraction, cAMP does not seem to influence the phosphorylation of the $50 \mathrm{~K}$ or $52 \mathrm{~K}$ proteins. Over a dose range of $10^{-4}-10^{-8} \mathrm{M}$ of cAMP no changes in endogenous phosphorylation of these proteins were observed (data not shown). 

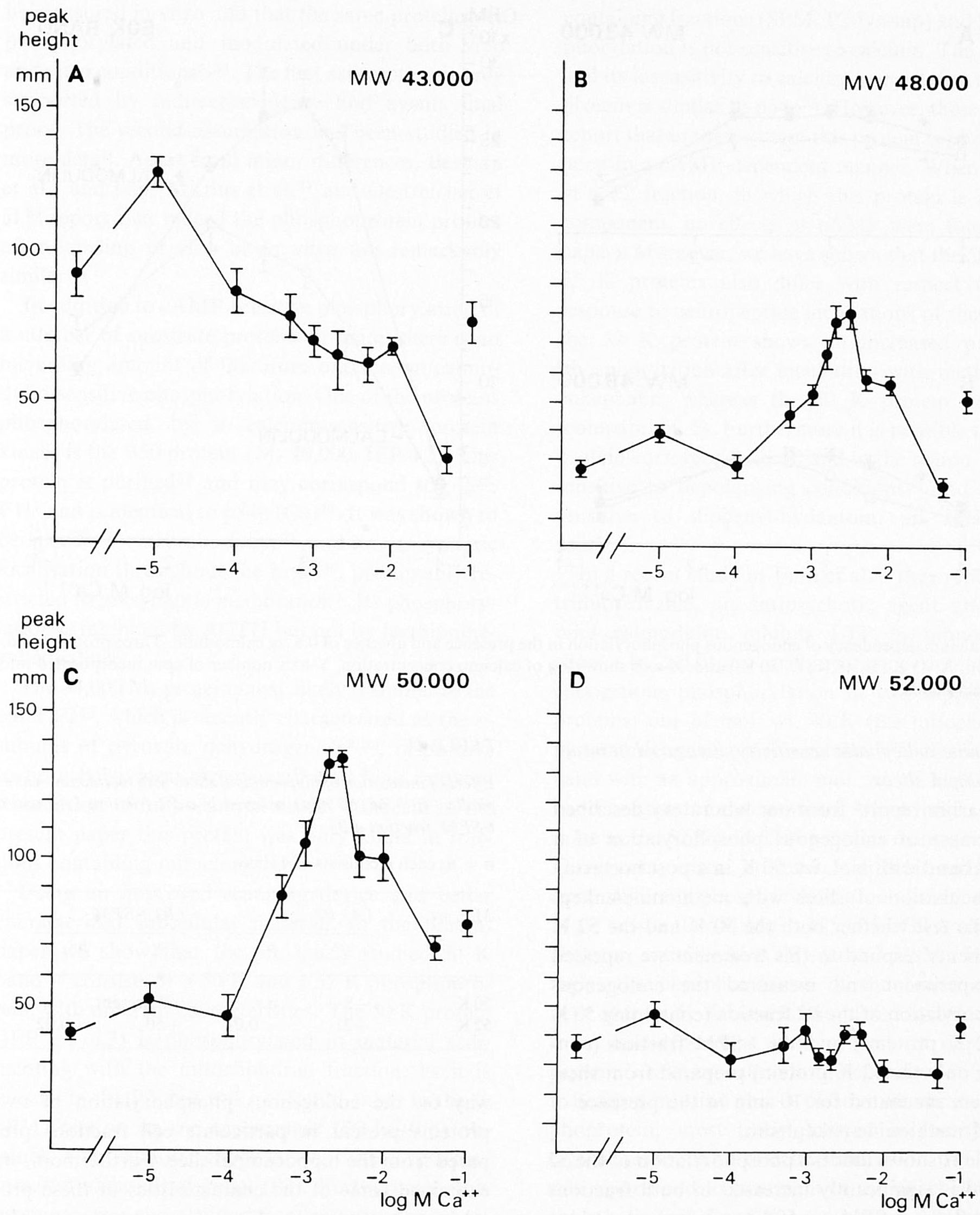

Fig. 5. Calcium dependency of endogenous phosphorylation for four proteins: A, $43 \mathrm{~K}$; B, $48 \mathrm{~K}$; C, $50 \mathrm{~K}$; D, $52 \mathrm{~K}$. On the X-axis, the $\log$ of calcium concentration is given, on the $\mathrm{Y}$-axis the peak height (above background) in mm measured after scanning autoradiographs. Single points (right side of each curve) represent the peak height when no exogenous Ca nor chelator is added ('standard' phosphorylation conditions). Means \pm S.E.M. (bars); $n$ is at least 4. 

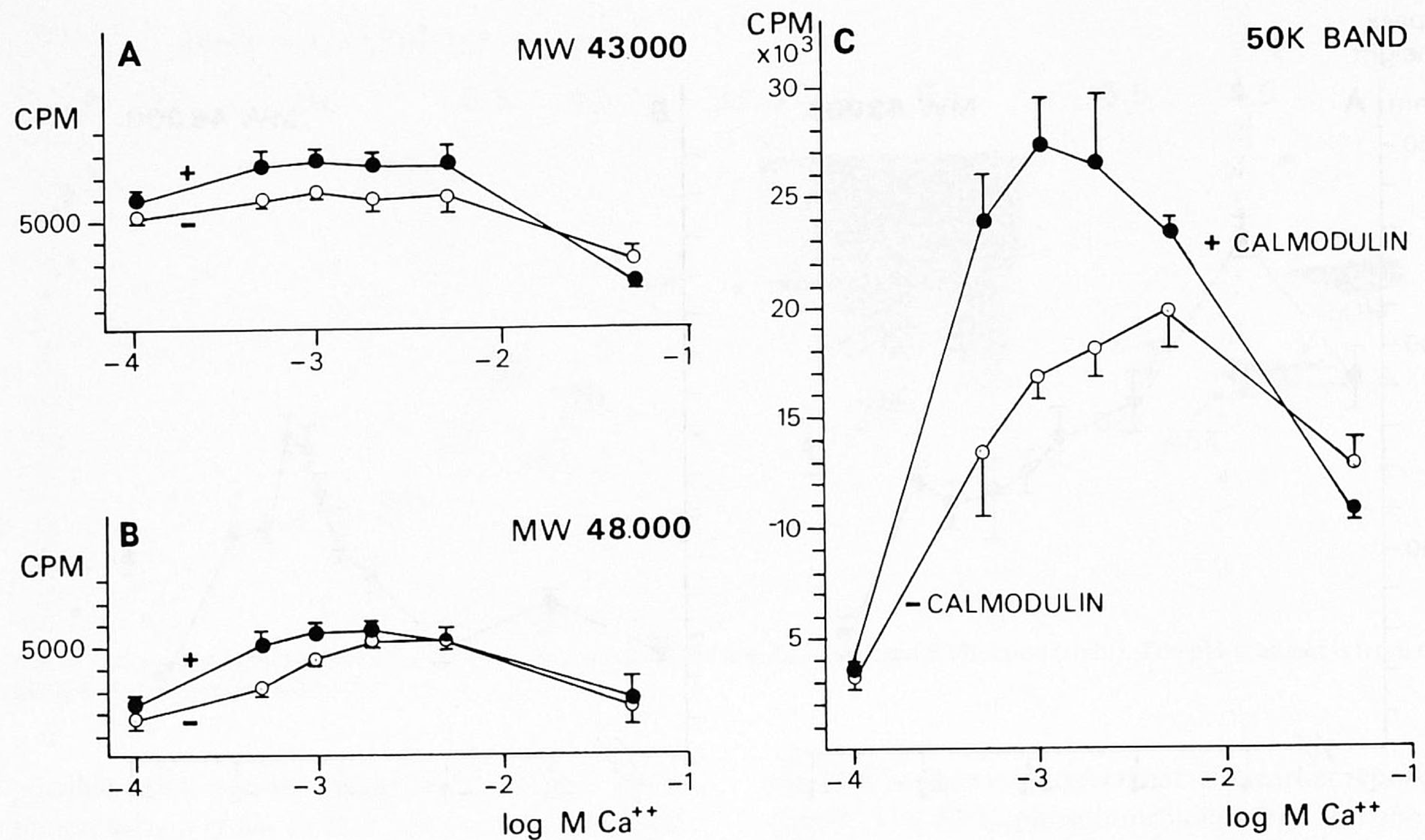

Fig. 6. Calcium dependency of endogenous phosphorylation in the presence and absence of $0.6 \mu \mathrm{g}$ calmodulin. Three protein bands are shown. A, $43 \mathrm{~K} ; \mathrm{B}, 48 \mathrm{~K} ; \mathrm{C}, 50 \mathrm{~K}$ band. X-axis shows $\log$ of calcium concentration, $\mathrm{Y}$-axis number of cpm incorporated into the protein bands.

\section{Methionine-enkephalin sensitivity, measured in intact} hippocampal slices

An earlier report ${ }^{5}$ from our laboratory described the increase of endogenous phosphorylation of a protein band with mol. wt. $50 \mathrm{~K}$ in a post hoc assay after incubation of slices with methionine-enkephalin. To test whether both the $50 \mathrm{~K}$ and the $52 \mathrm{~K}$ components respond to this treatment we repeated that experiment and measured the endogenous phosphorylation of the $\mathrm{P} 2$ fraction (containing $50 \mathrm{~K}$ and $52 \mathrm{~K}$ proteins) and the t-SPM fraction (containing only the $52 \mathrm{~K}$ protein) prepared from slices that were incubated for $10 \mathrm{~min}$ in the presence of $10^{-5} \mathrm{M}$ methionine-enkephalin.

Table II shows that the phosphorylation of the 52 $\mathrm{K}$ band is significantly increased in both fractions (P2: $+21 \%$; t-SPM: $+50 \%$ ), whereas the phosphorylation of the $50 \mathrm{~K}$ protein is not affected.

\section{DISCUSSION}

In this report we dealt with the effect of high frequent stimulation of a hippocampal synaptic path-
TABLE II

Effect of incubation of hippocampal slices with methionine-enkephalin $\left(10^{-5} \mathrm{M}, 60 \mathrm{~min}\right)$ assayed in a $P 2$ fraction $(A)$ and a $t-S P M$ fraction $(B)$

$\mathrm{n}=6$; each $\mathrm{n}$ consists of 4 slices.

\begin{tabular}{llllll}
\hline Mol.wt. & \multicolumn{2}{c}{ (A) $P 2$} & & & (B) $t-S P M$ \\
\cline { 2 - 3 } \cline { 5 - 6 } & $\triangle \%$ & $P$ & & $\triangle \%$ & $P$ \\
\hline $50 \mathrm{~K}$ & -8 & n.s. & & not present \\
$52 \mathrm{~K}$ & +21 & $<0.01$ & & +50 & $<0.02$ \\
\hline
\end{tabular}

way on the endogenous phosphorylation of two proteins present in particulate cell fractions prepared from the hippocampal slice. Furthermore, we examined some of the characteristics of these proteins: subcellular localization, molecular weight, IEP and the effects of various conditions (calcium, enkephalin, cAMP, calmodulin) on their phosphorylation in vitro.

The post hoc approach we used in this study and many others $4,10,14,16,26,54$ assumes that in vivo changes in endogenous protein phosphorylation can 
be measured in vitro and that the same proteins are phosphorylated and modulated under both vivo and vitro conditions ${ }^{5,54}$. The first assumption is only supported by indirect evidence and awaits final proof. The second assumption has been studied in more detail. Apart from minor differences, Berman et al. ${ }^{7}$ and later Mitrius et al. ${ }^{37}$ and Oestreicher et al. ${ }^{39}$ report that indeed the phosphoprotein profiles after labeling in vivo or in vitro are remarkably similar.

In addition to cAMP-sensitive phosphorylation of a number of substrate proteins in brain, there is an increasing amount of literature on calcium/calmodulin-sensitive phosphorylation. One of the proteins phosphorylated by a calcium-sensitive protein kinase is the $\mathrm{B} 50$ protein $\left(\mathrm{M}_{\mathrm{r}} 48,000\right.$, IEP 4.5$)$. This protein is purified ${ }^{53}$ and may correspond to $\gamma-5^{25}$, $\mathrm{F} 1^{17}$ and is identical to $\mathrm{p} 54 \mathrm{p}(\mathrm{Ca})^{34}$. It was shown to be specific for nervous tissue ${ }^{21}$ and has a synaptic localisation throughout the brain ${ }^{40}$, presumably restricted to presynaptic membranes ${ }^{45}$. Its phosphorylation is inhibited by ACTH but not by methionineenkephalin ${ }^{52}$.

The $43,000 \mathrm{M}_{\mathrm{r}}$ protein most likely is similar to the band F2 ${ }^{42}$, which is recently characterized as the $\alpha$ subunit of pyruvate dehydrogenase ${ }^{9,38}$, responsive to both behavioral experience ${ }^{41}$ and high frequent stimulation of hippocampal tissue ${ }^{10}$. Indeed, in the present paper this protein was only found in fractions containing mitochondria.

Using an improved scanning device and better characterized subcellular material, in the present paper we show that the previously studied $50 \mathrm{~K}$ band ${ }^{5,6}$ consists of a $50 \mathrm{~K}$ and a $52 \mathrm{~K}$ phosphoprotein, with different characteristics. The $50 \mathrm{~K}$ protein (IEP 3.5-4.3) is phosphorylated in material sedimenting with the mitochondrial fraction, as it is present in the $\mathrm{P} 2$, but was not found either in the $\mathrm{L}$ SPM fraction or the supernatant (P2-lys-sup) obtained after osmotic shock of the crude synaptosomal/mitochondrial pellet (P2). Furthermore, this protein is strongly calciumdependent in its phosphorylation and in the presence of calmodulin the calcium optimum is shifted towards lower concentrations of the divalent cation.

The other protein found in the $50 \mathrm{~K}$ band has a slightly higher mol. wt. (52 K), a less acidic IEP (5.3), is found predominantly in plasma membrane containing fractions (SPM, P2-lys-sup) and its phosphorylation is not sensitive to calcium. The IEP, $M_{r}$ and its insensitivity to calcium suggest that the $52 \mathrm{~K}$ protein is similar to $\mathrm{p} 54 \mathrm{p}^{35}$. However, these authors report that in their system this protein is phosphorylated in a cAMP-dependent manner. When studied in a $\mathrm{P} 2$ fraction, in which this protein is a minor component, no effects of cAMP were found (this paper). Moreover, we have shown that the $50 \mathrm{~K}$ and $52 \mathrm{~K}$ proteins also differ with respect to their response to neuropeptide incubations of slices: only the $52 \mathrm{~K}$ protein shows an increased post hoc phosphorylation after incubation with methionineenkephalin, whereas the $50 \mathrm{~K}$ protein does not (compare ref. 5). Furthermore it is possible that this protein corresponds to a band in the region of $50 \mathrm{~K}$ sensitive to depolarising conditions ${ }^{28}$ and a band sensitive to diphenyl-hydantoin, an anticonvulsant $^{11}$.

In a recent study of Finn et al. ${ }^{19}$ they report that trifluoperazine, an antipsychotic agent known to bind calmodulin, inhibits LTP in hippocampal slices. In addition, trifluoperazine inhibits the endogenous phosphorylation of two hippocampal proteins: one of mol. wt. $40 \mathrm{~K}$ (the mitochondrial pyruvate dehydrogenase $\alpha$-subunit $\left.{ }^{9,38}\right)$, the other is a band with an approximate mol. wt. of 51,000. This band consists of two proteins, which might be the same as the $50 \mathrm{~K}$ and $52 \mathrm{~K}$ proteins mentioned here. Direct comparison, however, is difficult, as they use quite different phosphorylation conditions $(1 \mathrm{mM}$ $\mathrm{Mg}^{2+}$ versus $10 \mathrm{mM} \mathrm{Mg}{ }^{2+}, 125 \mu \mathrm{M}$ EGTA versus no chelator, and $50 \mu \mathrm{M}$ ATP versus $7.5 \mu \mathrm{M}$ ). Interestingly, the phosphorylation of the lower component of their $51 \mathrm{~K}$ band is stimulated by calmodulin in a dose-dependent fashion, just as our $50 \mathrm{~K}$ protein is calcium/calmodulin-dependent.

Bearing in mind that a plasma membrane phosphoprotein, most likely located in the synaptic region, responds to electric stimulation (ref. 6 and this report) and to treatment of the intact slice with enkephalin (ref. 5 and this report) one is tempted to speculate on a functional correlation. Combining these data with the fact that: (1) methionine-enkephalin is present in the hippocampus in intrinsic peptidergic neurons ${ }^{20,27}$, which are believed to modulate other hippocampal neurons, and (2) the idea that enkephalins affect neuronal circuits in the 
hippocampus ${ }^{22,23,36}$, it might be postulated that long-term potentiation at least partly involves enkephalinergic neurons ${ }^{22,23}$ and that the $52 \mathrm{~K}$ protein is involved in the development and/or origin of this phenomenon.

The present study confirms and extends our observations of the change in protein phosphorylation after tetanic stimulation of the perforant path. The data show that the effects are confined to a $52 \mathrm{~K}$ protein (IEP 5.3), whose phosphorylation occurs in a calcium-independent manner. It is worth mentioning that the change in phosphorylation brought about by the tetanic stimulation itself is absolutely dependent on the presence of calcium ${ }^{6}$. The localization studies as carried out with various subcellular fractions point to a synaptic membrane rather than

\section{REFERENCES}

1 Alger, B. E. and Tyler, T. J., Long-term and short-term plasticity in the $\mathrm{CA}_{1}, \mathrm{CA}_{3}$ and dentate regions of the hippocampal slice, Brain Research, 110 (1976) 463-480.

2 Andersen, P., Bliss, T. V. P., Lømo, T., Olsen, L. I. and Skrede, K. K., Lamellar organization of hippocampal excitatory pahtways, Acta physiol. scand., 76 (1969) $4 \mathrm{~A}-5 \mathrm{~A}$.

3 Andersen, P., Bliss, T. V. P. and Skrede, K. K., Lamellar organization of hippocampal excitatory pathways, Exp. Brain Res., 13 (1971) 222-238.

4 Bär, P. R., Jolles, Oestreicher, A. B., Zwiers, H., van Someren, J., Schotman, P. and Gispen, W. H., Phosphorylation of membrane constituents: target of modulation by behaviourally active neuropeptides. In H. Matthies (Ed.), Mechanisms and Models of Neuroplasticity: the Role of Hippocampal Structures, Raven Press, New York, 1982, pp. 123-136.

5 Bär, P. R., Schotman, P. and Gispen, W. H., Enkephalins affect hippocampal membrane phosphorylation, Europ. $J$. Pharmacol., 65 (1980) 165-174.

6 Bär, P. R., Schotman, P., Gispen, W. H., Tielen, A. M. and Lopes da Silva, F. H., Changes in synaptic membrane phosphorylation after tetanic stimulation in the dentate area of the rat hippocampal slice, Brain Research, 198 (1980) 478-484.

7 Berman, R. F., Hullihan, J. P., Kinnier, W. J. and Wilson, J. E., Phosphorylation of synaptic membranes, J. Neurochem., 34 (1980) 431-437.

8 Browning, M., Bennet, W., Kelly, P. and Lynch, G., Evidence that the $40,000 \mathrm{M}_{\mathrm{r}}$ phosphoprotein influenced by high frequency synaptic stimulation is the alpha subunit of pyruvate dehydrogenase, Brain Research, 218 (1981) 255-266.

9 Browning, M., Bennet, W. and Lynch, G., Phosphorylase kinase phosphorylates a brain protein which is influenced by repetitive synaptic activation, Nature (Lond.), 278 (1979) 273-275.

10 Browning, M., Dunwiddie, T., Bennet, W., Gispen, W. a mitochondrial origin of the $52 \mathrm{~K}$ phosphoprotenn. Thus, in addition to the metabolic correlates discussed by Browning ${ }^{9}$ and Lynch and Schubert ${ }^{33}$ (energy metabolism and calcium in mitochondria), tetanic stimulation may indeed bring about changes in protein phosphorylation in synaptic membranes. Whether such changes are merely correlates or whether they indeed relate to the altered synaptic efficacy brought about by the stimulation is subject to further research.

\section{ACKNOWLEDGEMENTS}

The authors with to thank Lia Claessens for typing the manuscript and Ed Kluis for the artwork. Dr. A. J. Verkley's assistance in making the EM pictures was indispensable.

and Lynch, G., Synaptic phosphoproteins: specific changes after repetitive stimulation of the hippocampal slice, Science, 203 (1979) 60-62.

11 DeLorenzo, R. J. and Freedman, S. D., Possible role of calcium-dependent protein phosphorylation in mediating neurotransmitter release and anticonvulsant actions, Epilepsia 18 (1977) 357-365.

12 De Robertis, E., Alberici, M., Rodriguez de Lores Arnaiz, G. and Ascurra, J. M., Isolation of different types of synaptic membranes, Life Sci., 5 (1966) 577-582.

13 De Robertis, E. and Rodriguez de Lores Arnaiz, G., Structural components of the synaptic region. In A. Lajtha (Ed.), Handbook of Neurochemistry, Vol. II, Plenum Press, New York, 1969, pp. 365-392.

14 Dokas, L. A., Zwiers, H. and Gispen, W. H., Hormonal regulation of hippocampal synaptic plasma membrane protein phosphorylation, Neurosci. Abstr., (1981).

15 Dudek, F. E., Deadwyler, S. A., Cotman, C. W. and Lynch, G., Intracellular responses from granule cell layer in slices of rat hippocampus: perforant path synapse, J. Neurophysiol., 39 (1976) 383-393.

16 Ehrlich, Y. H., Davis, L. G. and Brunngraber, E. G., Effects of decapitationstress on the phosphorylation of cortical membrane proteins, Brain Res. Bull., 3 (1978) 251-256.

17 Ehrlich, Y. H., Davis, L. G., Gilgoil, T. and Brunngraber, E. G., Distribution of endogenously phosphorylated proteins in subcellular fractions of rat cerebral cortex, Neurochem. Res., 2 (1977) 533-548.

18 Fifková, E. and van Harreveld, A., Long-lasting morphological changes in dendritic spines of dentate granular cells following stimulation of the entorhinal areas, $J$. Neurocytol., 6 (1977) 211-230.

19 Finn, R. C., Browning, M. and Lynch, G., Trifluoperazine inhibits hippocampal long-term potentiation and the phosphorylation of a 40,000 dalton protein, Neurosci. Lett., 19 (1980) 103-108.

20 Gall, C., Brecha, N., Karten, H. J. and Chang, K.-J., Localization of enkephalin-like immunoreactivity to identified axonal and neuronal populations of the rat 
hippocampus, J. comp. Neurol., 198 (1981) 335-350.

21 Gispen, W. H., Jolles, J., Oestreicher, A. B. and Zwiers, H., Peptides and membrane phosphorylation, Progress in Brain Research, in press.

22 Haas, H. L. and Ryall, R. W., Presynaptic facilitation by enkephalin in the hippocampus, J. Physiol. (Lond.), 301 (1980) 37P-38P.

23 Haas, H. L. and Ryall, R. W., Is excitation by enkephalins of hippocampal neurones in the rat due to presynaptic facilitation or to dis-inhibition? J. Physiol. (Lond.), 308 (1980) 315-330.

24 Hjorth-Simonsen, A. and Jeune, B., Origin and termination of the hippocampal perforant path in the rat studied by silver impregnation, J. comp. Neurol., 144 (1972) 215-232.

25 Holmes, H. and Rodnight, R., Ontogeny of membranebound protein phosphorylating systems in the rat, Dev. Neurosci., 4 (1981) 79-87.

26 Holmes, H., Rodnight, R. and Kapoor, R., Effects of electroshock and drugs administered in vivo on protein kinase activity in rat brain, Pharmacol. Biochem. Behav., 6 (1977) 415-419.

27 Hong, J.-S. and Schmid, R., Intrahippocampal distribution of $\mathrm{Met}^{5}$-enkephalin, Brain Research, 205 (1981) 415-418.

28 Krueger, B. K., Forn, J. and Greengard, P., Depolarization induced phosphorylation of specific proteins, mediated by calcium influx, in rat brain synaptosomes, $J$. biol. Chem., 252 (1977) 2764-2773.

29 Lee, K., Oliver, M., Schottler, F., Creager, R. and Lynch, G., Ultrastructural effects of repetitive synaptic stimulation in the hippocampal slice preparation: a preliminary report, Exp. Neurol., 65 (1979) 478-480.

30 Lopes da Silva, F. H. and Arnolds, D. E. A. T., Physiology of the hippocampus and related structures, Ann. Rev. Physiol., 40 (1978) 185-216.

31 Lopes da Silva, F. H., Bär, P. R., Tielen, A. M. and Gispen, W. H., Longlasting post-tetanic potentiation in the dentate area of rat hippocampal slices and correlated changes in synaptic membrane phosphorylation. Progress in Brain Research, in press.

32 Lowry, O., Rosebrough, N. J., Farr, A. L. and Randall, R. J., Protein measurement with the Folin phenol reagent, J. biol. Chem., 193 (1951) 265-275.

33 Lynch, G. and Schubert, P., The use of in vitro brain slices for multidisciplinary studies of synaptic function, Ann. Rev. Neurosci., 3 (1980) 1-22.

34 Mahler, H. R., Kleine, L. P. and Sörensen, R. G., Topography of synaptic phosphoproteins, Trans. Amer. Soc. Neurochem., 12 (1981) 213, abstr. 287.

35 Mahler, H. R., Kleine, L. P. and Sörensen, R. G., Nature and topography of synapic phosphoproteins, Progress in brain Research, in press.

36 Martinez, J. L., Jensen, R. A., Creager, R., Veliquette, J., Messing, R. B., McGaugh, J. L. and Lynch, G., Selective effects of enkephalin on electrical activity of the in vitro hippocampal slice, Behav. neural. Biol., 26 (1979) 128-131.

37 Mitrius, J. C., Morgan, D. G. and Routtenberg, A., In vivo phosphorylation following ${ }^{32} \mathrm{P}$ orthophosphate injection into neostriatum and hippocampus: Selective and rapid labelling of electrophoretically separated brain proteins, Brain Research, 212 (1981) 67-81.

38 Morgan, D. G. and Routtenberg, A., Evidence that a 41,000 dalton brain phosphoprotein is pyruvate dehydrogenase, Biochem. bionhys. Res. Comm., 95 (1980) 569-576.
39 Oestreicher, A. B., Zwiers, H. and Gispen, W. H., Characterization of infant cortical membrane phosphoproteins phosphorylated in vivo, Proc. 22nd Dutch Fed. Meet., (1981) Abstr. 331.

40 Oestreicher, A. B., Zwiers, H., Schotman, P. and Gispen, W. H., Immunohisto-chemical localization of a phosphoprotein (B-50) isolated from rat brain synaptosomal plasma membranes, Brain Res. Bull., 6 (1981) 145-153.

41 Routtenberg, A. and Benson, G., In vitro phosphorylation of a $41,000 \mathrm{MW}$ protein band is selectively increased $24 \mathrm{hr}$ after footshock or learning, Behav. neural. Biol., 29 (1980) 168-175.

42 Routtenberg, A., Ehrlich, Y. H. and Rabjohns, R. R., Effect of a training experience on phosphorylation of a specific protein in neocortical and subcortical membrane preparations, Fed. Proc., 34 (1975) 17.

43 Schwarzkroin, P. and Wester, K., Long-lasting facilitation of a synaptic potential following tetanization in the in vitro hippocampal slice, Brain Research, 89 (1975) 107-119.

44 Skrede, K. K. and Westgaard, R. H., The transverse hippocampal slice: a well-defined cortical structure maintained in vitro, Brain Research, 35 (1971) 589-593.

45 Sørensen, R. G., Kleine, L. P. and Mahler, H. R., Presynaptic localization of phosphoprotein B-50, Brain Res. Bull., (1981) in press.

46 Terenius, L., Stereospecific interaction between narcotic analgesics and a synaptic plasma membrane fraction of rat cerebral cortex, Acta pharmacol. toxicol., 32 1973) 317-320.

47 Tielen, A. M., Lopes da Silva, F. H., Bär, P. R. and Gispen, W. H., Long-lasting post-tetanic stimulation in the dentate area of rat hippocampal slices and correlated changes in synaptic membrane phosphorylation. In $\mathrm{H}$. Matthies (Ed.), Mechanisms and Models of Neuroplasticity: the Role of Hippocampal Structures, Raven Press, New York, 1982, pp. 239-254.

48 Tielen, A. M., Lopes da Silva, F. H. and Mollevanger, W. J., Differential conduction velocities in perforant path fibers in guinea pig, Exp. Brain Res., 42 (1981) 231-233.

49 Ueda, T., Maeno, H. and Greengard, P., Regulation of endogenous phosphorylation of specific proteins in synaptic membrane fractions from rat brain by adenosine 3',5'-monophosphate, J. biol. Chem., 248 (1973) 8295-8305.

50 Wallace, R. W. and Cheung, W. Y., Calmodulin: production of an antibody in rabbit and development of a radioimmunoassay, J. biol. Chem., 254 (1979) 6564-6571.

51 Yamamoto, C. and McIlwain, M., Electrical activities in thin sections from the mammalian brain maintained in chemically-defined media in vitro, J. Neurochem., 13 (1966) 1333-1343.

52 Zwiers, H., Veldhuis, H. D., Schotman, P. and Gispen, W. H., ACTH, cyclic nucleotides and brain protein phosphorylation in vitro, Neurochem. Res., 1 (1976) 669-677,

53 Zwiers, H., Schotman, P. and Gispen, W. H., Purification and some characteristics of an ACTH-sensitive protein kinase and its substrate protein in rat brain membranes, J. Neurochem., 34 (1980) 1689-1700.

54 Zwiers, H., Wiegant, V. M., Schotman, P. and Gispen, W. H., Intraventricular administered ACTH and changes in rat brain protein phosphorylation: a preliminary report. In Roberts et al. (Eds.), Mechanisms, Regulation and Special Function of Protein Synthesis in the Brain, Elsevier/North-Holland Biomedical Press, Amsterdam, 1977, pp. 267-272. 